press in West Africa is negligible; even the publicist and the most nationally minded writers express their ideas in English. Intentionally or otherwise one great result of this action is that they are assisting the decay of their own tongues, or at the very least are failing to assist them to keep abreast of the times in which they live.

To sum up, definite steps must be taken by Europeans to encourage the forming and adoption of new words to express the various ideas which must now form part of the consciousness of the African if he is to use his own language as a thinking medium. To avoid offences against the speech-feeling of a language the work will be best done by Africans, but they will need guidance. Where words do not naturally grow they must be coined. If they fit an international need so much the better, but they must at any rate be capable of ready assimilation by being euphonically consistent with the language. Lengthy circumlocutions are best avoided; dialects may provide much material for words in a specialized sense. The press may give some assistance but the teacher will give most. The rigid conservatism of the older men may be disregarded; it will be quite enough if we get at the younger generations by the help of the school staffs and fit them for the problems and situations they will have to face.

\title{
The Study of African Life and Languages in South Africa.
}

It is the common experience of new countries that the European rulers have rarely shown real interest in the customs and institutions of their subject tribes. South Africa forms no exception to this rule. Accounts of Native life were published by travellers and missionaries, the Bible was translated into various native dialects, and a number of grammars were written. The general public, however, paid little attention to this kind of literature, nor was any pressure brought to bear upon the government to study the social life of its native subjects. Sir George Grey was, I believe, the only high official who actively encouraged linguistic research. His librarian, Dr. Wilhelm Bleek, laid a sound foundation for the development of Bantu philology with his scholarly Comparative Grammar of South African Languages and collected valuable material for the study of Bushman languages. Sir George's enlightened policy was unfortunately not continued by his successors in office, and the study of native culture was once more left to missionaries and visiting scholars from Europe. In South Africa Native customs were apparently not considered worthy of scientific investigation nor of official recognition. Only Native law had of necessity to be taken into consideration by the law courts. The general attitude of the South African public is well illustrated by the fact that a number of books could be published on the almost extinct Bushman people while the thriving Bantu tribes were practically neglected.

This state of affairs continued until quite recently. Evidence concerning 
the native population was collected in one or two official blue books, but no real attempt was made to initiate ethnological research. The study of Bantu Life and Languages had found no place in the curriculum of any of the universities until after the Great War, and no other facilities whatsoever were provided for the training of Native Commissioners in these subjects.

Nevertheless the credit for breaking away from this attitude of indifference belongs to the government of South Africa which was in power some fifteen years ago. The Minister of Education realized the urgent necessity of stimulating anthropological and linguistic research. The University of Capetown and a little later the University of the Witwatersrand were chosen as the most suitable centres and were given liberal grants towards the establishment of Schools of Native Life and Languages. Of these grants a substantial sum had to be expended on research work. A few years later a Government ethnologist was appointed to advise the Department of Native Affairs.

In 1926 the University of Stellenbosch also instituted degree courses in Bantu Languages and Social Anthropology, and the University of Pretoria soon followed suit. Unfortunately the efforts of the latter two Universities to obtain from the Government the same grants-in-aid as were received by Johannesburg and Capetown proved fruitless. Even worse was to follow, for the Minister of Education, having satisfied himself that Bantu Studies were now well under way, saw fit to abolish all such grants. As soon as this had happened the various constituent colleges of the University of South Africa which had been clamouring for the right to establish chairs in Native Languages and Social Anthropology immediately abandoned their propaganda in this direction.

At present the Universities of Capetown, Stellenbosch, Johannesburg, and Pretoria all offer full degree courses in Native Life and Languages, while the University of South Africa acts as examining body for an ever-growing number of external students who present themselves for examination in these subjects. The only constituent college of the University of South Africa which also offers instruction in African Studies is the Native College at Fort Hare.

The number of students who take these courses is steadily increasing. In 1933 approximately roo students at Stellenbosch attended the lectures in Anthropology and Bantu Languages, and two senior students, who had been doing field-work in Rhodesia and Swaziland respectively, had their theses accepted for the Ph.D. degree. If I am correctly informed the figures at the other universities are not so high as at Stellenbosch, but it is quite evident that the scientific study of African life has come to stay. Even in those university centres where no direct instruction in these subjects is to be had Bantu Studies Circles have sprung up, for the academic youth in South Africa is now deeply interested in the present condition and the future development of the Native population.

In connexion with the teaching of both social anthropology and African 
languages there are some serious difficulties. As regards languages the real crux is this, that so many Bantu dialects (Zulu, Xosa, Sotho, Chwana, Pedi, Nyanja) must be taught and that the work has to be done by one or two persons only in every case. It follows that these lecturers can devote very little time to further research. In the case of social anthropology the difficulty is of another nature. The South African anthropologists are all agreed that in a country like South Africa, with its large Native population, anthropology must not remain an abstract science dealing with conditions of the long-forgotten past only and with customs that are already extinct. They are convinced that anthropology must also serve a practical purpose and must devote itself to the investigation of recent developments in Native life. It is certainly just as important to know how the Cape Coloured and the changing Native of to-day live and think as it is to have a thorough knowledge of the mental and social activities of the Hottentots and Bantu of past generations. At present, however, so little reliable information is available concerning our modern non-Europeans, that it is hardly feasible to make them the subject of more than a few university lectures each year.

Scientific research to close up these gaps in our knowledge is most urgently needed, but, since the South African grants for this particular type of investigation have been withdrawn, the work is bound to proceed very slowly. Of course the Institute actively encourages research along these lines within the limits of its available funds.

A certain amount of anthropological and linguistic research is being done under the auspices of the South African Universities, and thanks to the expert advice given to individual field workers by the Inter-University Committee on African Studies there has lately been very little duplication or overlapping of research work. It is to be hoped that this body will be able to promote the development of African Studies effectively through its co-ordinating activities. Its co-operation with the Institute helps it to secure the services of the most competent field workers for the most urgent tasks.

(Communicated by Dr. WERnER EISELEN.)

\section{Le Probleme de l'éducation indigène dans la Colonie de Mogambique.}

A quoi en est le problème de l'éducation indigène dans la Colonie Portugaise de l'Est-Africain? Deux volumes ont paru ces dernières années qui peuvent nous renseigner, tous deux d'environ 300 pages: ce sont les Annuaires de l'Enseignement dans la Colonie de Mocambique publiés par le département de l'Instruction Publique pour les années 1930 et 1931. Le second est sorti de presse il y a quelques mois. Ces deux volumes ont un grand intérêt pour ceux qui s'occupent du développement des Indigènes de l'Afrique méridionale et équatoriale.

Inutile de parler ici de ce qui a été fait autrefois; des lois et décrets ont été 